\title{
A CATILINÁRIA DE MONTEIRO LOBATO: UMA ANÁLISE RETÓRICA DO ARTIGO A PROPÓSITO DA EXPOSIÇÃO MALFATTI ${ }^{[1]}$
}

\author{
MONTEIRO LOBATO'S CATILINARIAN: A RHETORICAL \\ ANALYSIS OF THE ARTICLE A PROPÓSITO DA EXPOSICÃO \\ MALFATTI
}

LE CATILINAIRE DE MONTEIRO LOBATO: UNE ANALYSE RETRICALE DE L'ARTICLE A PROPÓSITO DA EXPOSICÃO MALFATTI

\section{RESUMO}

Com este trabalho nos propomos a perscrutar retoricamente $\mathrm{O}$ artigo "A propósito da exposição Malfatti", do escritor Monteiro Lobato, publicado em 20 de dezembro de 1917 e elaborado a designo da exposição de pintura moderna da artista plástica Anita Malfatti, precursora da arte moderna brasileira. Destarte, analisa-se as nuances retóricas do discurso proferido por Lobato, averiguando sua estrutura retórica e argumentativa; 0 ethos construido pelo autor; e as paixões realçadas pelo discurso. $\bigcirc$ artigo fundamenta-se sobre $\mathrm{O}$ alicerce teórico da Retórica, com os estudos de autores como Aristóteles (2015), Perelman e Olbrechts-Tyteca (2005), Meyer (2007), Reboul (2004), Fiorin (2014), e Tavares (1978). Sobre Malfatti, sua obra e o contexto cultural de sua

\section{ABSTRACT}

With this work we propose to rhetorically examine the article A Propósito da Exposição Malfatti written by Monteiro Lobato on December 20, 1917, for the exhibition of the modern painting by the artist Anita Malfatti, a forerunner of Brazilian modern art. Thus, we analyze the rhetorical nuances of Lobato's discourse by investigating his rhetorical and argumentative structure; the ethos of the author; and the passions highlighted by the discourse. The article is based on authors such as Aristotle (2015), Perelman and Olbrechts-Tyteca (2005), Meyer (2007), Reboul (2004), Fiorin (2014) and Tavares (1978). To talk about Malfatti's work and the cultural context of that time, we consider discussing the works of Batista (2006) and Coelho (2012). The use of rhetorical features in the

\section{RÉSUMÉ}

Avec ce travail, nous proposons d'examiner de manière rhétorique l'article "Concernant l'exposition Malfatti", de l'écrivain Monteiro Lobato, publié le 20 décembre 1917 et élaboré pour l'exposition de peinture moderne de l'artiste Anita Malfatti, précurseur de l'art. brésilienne moderne. Ainsi, nous analysons les nuances rhétoriques du discours donné par Lobato en étudiant: sa structure rhétorique et argumentative; l'éthos construit par l'auteur; et les passions mises en évidence par le discours. L'article est basé sur les fondements théoriques de la rhétorique, avec des études d'auteurs tels qu'Aristote (2015), Perelman et Olbrechts-Tyteca (2005), Meyer (2007), Reboul (2004), Fiorin (2014) et Tavares (1978). À propos de Malfatti, de son cuvre et du contexte culturel de son époque, nous 
época, consideraremos os trabalhos de Batista (2006) e Coelho (2012). O uso de recursos retóricos no discurso caracteriza a catilinária de Lobato, que atinge o auditório da época e desperta paixões.

\section{Palavras-chave:}

Retórica; Arte Moderna;

Monteiro Lobato; Anita Malfatti.

\section{INTRODUÇÃO}

A semana sem fim, como alguns denominam A Semana de Arte Moderna de 1922, consolidou o movimento artístico e literário modernista, que reverbera hodiernamente, dando alicerce para outros movimentos artísticos e consolidando novas formas de arte.

O Modernismo no Brasil teve seu início oficial na Semana de Arte Moderna de 22, realizada na cidade de São Paulo, em 1922. A "Semana de 22" é considerada relevante para o rompimento com o tradicionalismo cultural que se associava às correntes literárias e artísticas anteriores, como o Parnasianismo, escola literária de essência poética; o Simbolismo, corrente artística de cunho espiritualista, vinda da França; e a Arte Acadêmica ou Academicismo, termo ligado às academias de artes plásticas, onde a criação era pautada na forma artística predeterminada, padronizada e ancorada no ensino prático.

Anita Catarina Malfatti foi uma importante artista plástica, precursora da Arte Moderna no Brasil. Sua trajetória a tornou speech characterizes Lobato's catilinarian that reaches the auditorium of the time and arouses passions.

\section{Keywords:}

Rhetoric; Modern Art; Monteiro Lobato; Anita Malfatti.

uma das mais importantes artistas da história da arte em nosso país.

A partir de sua biografia e estudo de obra escritos pela historiadora brasileira Marta Rossetti Batista, Anita Malfatti no tempo e no espaço (2006), fica manifesta a dicotomia que sempre permeou sua vida, seja no que se refere às artes plásticas, ou a outras vicissitudes. Malfatti esteve constantemente em bifurcações conflituosas em sua maneira de enxergar a arte, alterando-se entre momentos de êxtase e de superação, ou entre seguir sua arte "rebelde" ou desenvolver a arte que atendia ao status quo, sendo a primeira a arte moderna que a pintora trouxe da Europa e a outra a Arte Acadêmica vigente naquele momento histórico no Brasil.

Malfatti retorna da Europa, após árduo estudo no campo da arte, para em 1917 apresentar ao país 53 de suas obras, dentre elas, pinturas, paisagens, gravuras, aquarelas, caricaturas e desenhos, exibindo-as em sua segunda exposição[2], intitulada Exposição de Pintura Moderna considérerons les œuvres de Batista (2006) et Coelho (2012).

L'utilisation des ressources rhétoriques dans le discours caractérise le cathillaire de Lobato, qui atteint I'auditorium de l'époque et suscite des passions.

\section{Les Mots clés:}

La Rhétorique; L'Art moderne; Monteiro Lobato; Anita Malfatti.

Anita Malfatti. Essa exposição funcionou como um gatilho para o surgimento da Arte Moderna no Brasil, e para reações passionais de críticos e futuros modernistas, que foram das paixões de ira, irritação e inveja à amabilidade, devoção, amizade e amor pela artista. Como exemplos, temos a crítica ferrenha do escritor Monteiro Lobato, no artigo A propósito da exposição de Malfatti publicado primeiramente no jornal O Estado de SP em 1917[3], onde o criador da boneca Emília toma Malfatti como "louca" e sua arte como "estranhas psicoses" (BATISTA, 2006)

Em contrapartida, houve a alcunha de "arte nova" de alguns modernistas, tais como Mário de Andrade e Oswald de Andrade, que aderiram favoravelmente ao trabalho de Malfatti, definindo-o como "marco inicial do movimento modernista" (BATISTA, 2006, p. 17) e "estopim do modernismo". [4] Ambos os escritores também a consideraram uma pioneira, com uma obra divisora de águas.

Monteiro Lobato foi escritor, jornalista e editor brasileiro de 
grande prestígio. Um dos primeiros autores de literatura infantil do país e de toda a América Latina. Sobressaiu-se nesse segmento com sua obra de maior destaque: "O Sítio do Pica-pau Amarelo".

Para tanto, o intuito neste trabalho é analisar a estrutura retórica e argumentativa do artigo A propósito da exposição de Malfatti (ou Paranóia e mistificação?)[5], de Monteiro Lobato, publicado na semana da referida exposição, além de averiguar as paixões realçadas por tal discurso. Utilizaremos, para tal, o alicerce teórico da Retórica, mais precisamente, estudos de autores como Aristóteles (2015), Perelman e Olbrechts-Tyteca (2005), Meyer (2007), Reboul (2004), Fiorin (2014), e Tavares (1978). Além de averiguar a biografia de Malfatti e sua obra no contexto cultural da época, considerando os trabalhos de Batista (2006).

A análise se dará averiguando como se dispôs o uso de recursos retóricos, como figuras e tropos, no discurso de Lobato, que atingiu seu auditório, despertando paixões e emoções. Além de evidenciar, por meio do discurso, como tais paixões foram sendo provas da efetivação do intento do autor de argumentar sobre seu posicionamento a respeito do que se configura arte, caracterizando a exposição como algo que não se inclui no conceito de arte que ele demonstra em sua fala. Desempenhando, portanto, seu desígnio retórico que compreende valores em comum com seu auditório.

\section{ESTRUTURA RETÓRICA E} ARGUMENTATIVA
Como ciência, arte e disciplina, a Retórica teve seu primórdio grafado e estabelecido pelo grande filósofo Aristóteles. Contudo, antes mesmo do grande estagirita[6], a arte da eloquência ou facúndia já se enveredava por entre os povos gregos, esmiuçando os caminhos para a persuasão.

A definição de Aristóteles (2015, p. 62), o grande formulador da teoria retórica, outorga que "entendamos por retórica a capacidade de descobrir o que é adequado a cada caso com o fim de persuadir". Isso feito, pode-se compreendê-la como uma competência que o orador possua ou desenvolva, buscando encontrar, dentre várias opções argumentativas acessíveis, aquelas que em cada caso persuadirão de forma mais adequada, ou seja, trata da maneira mais propícia, em cada situação, de obter a adesão de um auditório.

Portanto, tomando como ponto as definições dadas por Perelman e Olbrechts-Tyteca (1996, p. 7) sobre o discurso, o orador e o auditório, concebese esses três pilares, sendo "a argumentação, aquele que a apresenta e aqueles a quem ela se dirige, sem nos determos no fato de que se trata de uma apresentação pela palavra ou pela escrita, sem distinguir em forma e expressão fragmentária do pensamento". Dessa forma, compreende-se que o artigo analisado se concebe como um discurso proferido por um orador, O escritor Monteiro Lobato, destinado a um auditório, e com vistas a persuadi-lo.

Logo, o ethos diz respeito ao caráter, honra, ou virtude atribuída ao orador, a imagem que ele constrói de si no seu discurso. Dessa forma, Meyer (2007, p. 26) diz que do ponto de vista do orador, o determinante para o discurso é se ele agradará o auditório e a maneira utilizada para esse intuito pode ser tanto por meio de um discurso agradável ou belo, como por meio de um argumento.

No artigo, O escritor Monteiro Lobato se coloca no texto como defensor da Arte Acadêmica, e com isso, opõe-se à Arte Moderna e às referências de escolas plásticas europeias trazidas por Malfatti.

Nesse processo, Lobato constrói seu ethos, a imagem de crítico conhecedor das artes plásticas e que tem a Arte Clássica ou Acadêmica como a única "arte" a ser considerada correta. Assim, o escritor promove a Arte Acadêmica na seguinte passagem, "Todas as artes são regidas por princípios imutáveis, leis fundamentais que não dependem do tempo nem da latitude. As medidas de proporção e equilíbrio, na forma ou na cor, decorrem de que chamamos sentir". (LOBATO 1917, n.p.). Pois, a Arte Acadêmica é a criação pautada na forma artística predeterminada, padronizada e ancorada no ensino prático, pintando de forma mais fiel possível à realidade do mundo natural, diferente da Arte Moderna que conduz a arte pelas expressões, pelos sentimentos despertados por meio da forma, da cor, da profundidade ou não, etc.

Prosseguindo com o tripé aristotélico, para o linguista 
Reboul (2004, p. 92-93) "sempre se argumenta diante de alguém. Esse alguém, que pode ser um indivíduo ou um grupo ou uma multidão, chama-se auditório, termo que se aplica até aos leitores". O auditório citado por Meyer, e explicitado por Reboul, constitui-se dos ouvintes, leitores ou espectadores que participam do discurso, aderindo ou não a esse, sendo persuadidos ou não, estando dispostos às paixões despertadas ou não.

Reboul (2004, p. 92-93) ainda caracteriza o auditório, acrescentando "um auditório é, por definição particular, diferente de outros auditórios. Primeiro pela competência, depois pela crença e finalmente pelas emoções".

Aqui, constata-se que o auditório é composto pelas crenças ou valores e, ainda, pelo pathos despertado, ou seja, as paixões, que, de acordo com Meyer (2007, p. 36), "é a fonte das questões e estas respondem a interesse múltiplos, dos quais são prova as paixões, as emoções ou simplesmente as opiniões".

Meyer (2007, p. 22) discorre ainda sobre o último tripé da retórica:

O lógos subordina a suas regras próprias o orador e - auditório: ele persuade um auditório pela força de seus argumentos, ou agrada a esse mesmo auditório pela beleza do estilo, que comove aqueles a quem se dirige. [...] Mas é o lógos que faz diferença entre o discurso racional e aquele que provoca paixões, criando emoções e chegando mesmo a fazer com que a razão seja esquecida.
$O$ ethos veiculado pelo artigo constrói o ethos de escritor e também o de crítico de artes plástica de Lobato. Constata-se isso, pela habilidade com as palavras, pelo uso de metáforas, metonímias, recursos estilísticos e retóricos e pelo conhecimento engendrado em artes.

Os autores Perelman e Olbrechts-Tyteca (1996, p. 73) discorrem:

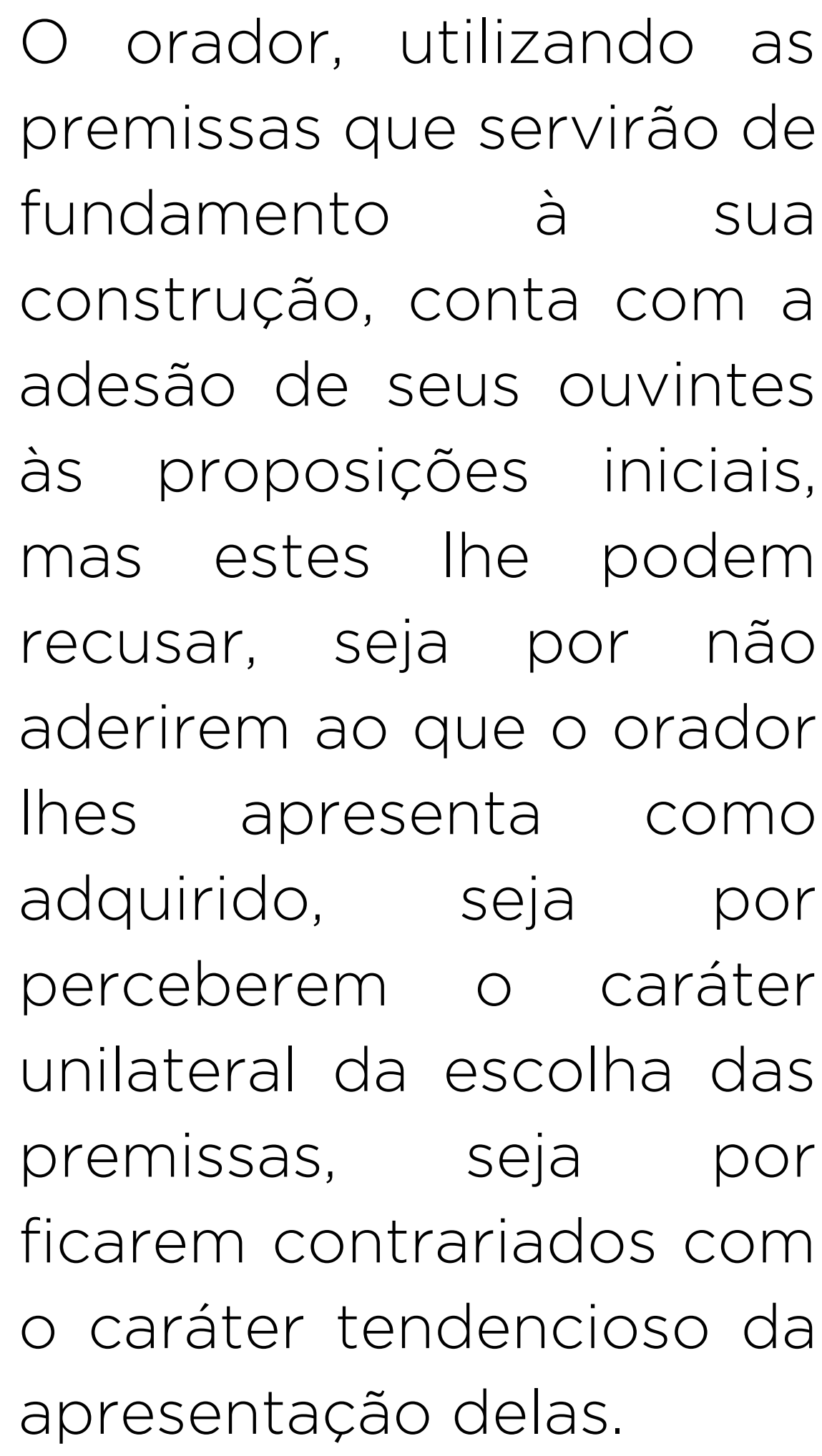
premissas que servirão de fundamento à sua construção, conta com a adesão de seus ouvintes às proposições iniciais, mas estes the podem recusar, seja por não aderirem ao que o orador Ihes apresenta como adquirido, seja por perceberem o caráter unilateral da escolha das premissas, seja por ficarem contrariados com o caráter tendencioso da apresentação delas.

Percebe-se como Lobato se utiliza das premissas retóricas para obter a adesão do auditório. Nesse caso, demostrando habilidade com as palavras e conhecimento específico sobre arte, como que para externar aos ouvintes que possuía a autoridade necessária para tanto.

Compreende-se aqui que o logos é uma instância associada ao discurso proferido pelo autor/crítico, e o pathos uma instância ligada ao auditório, no caso do texto em nálise, a sociedade brasileira da época, mais especificamente, críticos, artistas e partícipes.

Deste modo, em um discurso retórico são apontadas estratégias estruturais que precisam ser seguidas, consciente

OU inconscientemente, para um discurso harmônico e adequado. No que diz respeito a esses aspectos, referimo-nos às partes do discurso. Nesse sentido, temse essas subdivisões tradicionais elaboradas por Cícero (apud MEYER, 2007a, p. 23).

\begin{abstract}
As partes (da retórica) são a invenção, e a disposição a elocução, a memória e a maneira de falar. A invenção compreende a investigação das razões verdadeiras ou verossímeis que podem apoiar a causa; a disposição consiste em colocar essas razões por ordem; a elocução tem por objectivo adequar as palavras e os pensamentos aos meios fornecidos pela invenção. A memória tem por objectivo gravar fielmente os pensamentos no espírito. A maneira de falar, por fim, regula gesto e a voz e harmonizaos com $O$ assunto e a linguagem.
\end{abstract}

Já para Reboul (2004, p. 43) são quatro as partes ou fases que compõe o discurso, sendo elas a invenção, a disposição, a elocução e a ação. A invenção (heurésis, em grego) é a "busca que empreende $\mathrm{o}$ orador de todos os argumentos e de outros meios de persuasão relativos ao tema do seu discurso".

A disposição (taxis) se configura como a ordenação dos argumentos estabelecidos anteriormente, sendo, dessa forma, a organização interna do discurso. A elocução (lexis) é a palavra escrita do discurso, seu estilo. E, por fim, a ação (hypocrisis), o ato de proferir o discurso. (REBOUL, 2004, p. 4344).

Como corroboração, o linguista 
Meyer exemplifica (2007, p. 24), a invenção é "uma questão, um problema, uma causa". No artigo de Lobato, a questão dada é a "nova arte" proposta pela artista, que ele não reconhece como tal, já que sua questão quanto à arte já está resolvida, e se configura como a Arte Acadêmica. Nesse sentido, o escritor levanta elementos favoráveis em sua defesa ao Academicismo, suscitando respostas que o auditório, que já havia visitado a exposição de Malfatti, não tinha, respondendo às perguntas "não-formuladas" por esse auditório.

As perguntas "não-formuladas" surgem nas paixões despertadas, onde a pergunta se torna resposta, que conforme Meyer (2007b, p. 38) "quanto mais estivermos na paixão, mais já teremos respondido" a algo. O autor ainda acrescenta que "a paixão é retórica por enterrar as questões nas respostas que fazem crer que elas já estão resolvidas". Dessa forma, concebe-se que o auditório, que foi despertado em suas paixões pelo artigo de Lobato, teve suas perguntas "não-formuladas" sobre arte respondidas pelo discurso do escritor, que mostrou seu intento em defender a Arte Acadêmica em oposição à Arte Moderna.

No momento em que Lobato encontra sua resposta sobre a nova arte de Malfatti, ele a expõe em um artigo, pois o escritor sabe das crenças e valores de seu auditório no que se refere à Arte Moderna. Assim ele cumpre a disposição, mais uma etapa para a elaboração de um discurso retórico, que segundo Meyer (2007a, p. 24, grifos nossos), configura-se como o passo na qual o orador "coloca as ideias em ordem e as estrutura segundo um espaço plausivel ou racional. Para isso, apoia-se tanto em factos como nas verossimilhanças, tanto nas evidências quanto nas paixões e nas opiniões". Aqui, o filósofo reforça que na invenção "coabitam a argumentação e a passionalidade".

Na disposição, deve-se identificar qual o tipo de discurso ou gênero será empregado. Para tanto, Reboul (2004, p. 44) apresenta os três gêneros oratórios do discurso dispostos por Aristóteles, sendo eles, o judiciário, o deliberativo e o epidíctico. Os três gêneros, respectivamente, acusam ou defendem, aconselham ou desaconselham e, por fim, censuram ou louvam.

Ainda segundo Meyer (2007a p. 24), a disposição engloba elementos essenciais da argumentação:

Para captar o público é
preciso chamar a sua
atenção para a questão: a)
pelo exórdio; b) a seguir
convém proceder à
narração dos factos,
expondo a solução e
argumentando a favor e
contra, antes de retornar
ao todo c) pela peroração,
que sintetiza e mostra a
adequação da solução ao
problema colocado.

Dos elementos elencados, Perelman e Olbrechts-Tyteca recordam que Aristóteles compara o exórdio ao prólogo e ao prelúdio, transformando-o em um acessório, cuja acepção seria principalmente estética. Contudo, "em muitos casos ele é indispensável para o efeito persuasivo do discurso. Garante as condições prévias para a argumentação". (PERELMAN; OLBRECHTSTYTECA, 1996, p. 561).
Por isso, o exórdio manifesta-se em seu parágrafo inicial, no qual Lobato faz uma comparação colocando os grandes artistas da Arte Clássica, tais como: Rafael, Rembrandt e outros mais, como modelos de equilíbrio, ao passo em que coloca os artistas que fazem Arte Moderna como senis, anormais e/ou efêmeros.

\section{Lobato age como}

se separasse o joio do trigo, proferindo ao seu auditório: artistas. Uma composta dos que vêem normalmente as coisas e em conseqüência disso fazem arte pura [...]. Quem trilha por esta senda, se tem gênio, é Praxíteles na Grécia, é Rafael na Itália, é Rembrandt na Holanda, é Rubens na Flandres, é Reynolds na Inglaterra, é Leubach na Alemanha, é Iorn na Suécia, é Rodin na França, é Zuloaga na Espanha. Se tem apenas talento vai engrossar a plêiade de satélites que gravitam em torno daqueles sóis imorredoiros.

A outra espécie é formada pelos que vêem anormalmente a natureza, e interpretam-na à luz de teorias efêmeras, sob a sugestão estrábica de escolas rebeldes, surgidas cá e lá como furúnculos da cultura excessiva. São produtos de cansaço e do sadismo de todos os períodos de decadência: são frutos de fins de estação, bichados ao nascedouro. Estrelas cadentes, brilham um instante, as mais das vezes com a luz de escândalo, e somem-se logo nas trevas do esquecimento.

Embora eles se dêem como novos precursores duma arte a ir, nada é mais velho de que a arte 
anormal ou teratológica: nasceu com a paranóia e com a mistificação. De há muitos já que a estudam os psiquiatras em seus tratados, documentandose nos inúmeros desenhos que ornam as paredes internas dos manicômios. A única diferença reside em que nos manicômios esta arte é sincera, produto ilógico de cérebros transtornados pelas mais estranhas psicoses; e fora deles, nas exposições públicas, zabumbadas pela imprensa e absorvidas por americanos malucos, não há sinceridade nenhuma, nem nenhuma lógica, sendo mistificação pura. (LOBATO, 1917, n.p.)

Nesta ocasião, Lobato arremata que todas as artes devem ser pautadas em medidas e proporções fieis à uma realidade milimétrica e matematicamente efetuada para pintar o "real" natural do mundo. Concedendo um lugar de "não-arte" às pinturas distorcidas e efusivamente pintadas de Malfatti.

Todas as artes são regidas por princípios imutáveis, leis fundamentais que não dependem do tempo nem da latitude. As medidas de proporção e equilíbrio, na forma ou na cor, decorrem de que chamamos sentir Quando as sensações do mundo externo transformam-se em impressões cerebrais, nós "sentimos"; para que sintamos de maneiras diversas, cúbicas ou futuristas, é forçoso ou que a harmonia do universo sofra completa alteração, ou que o nosso cérebro esteja em "pane" por virtude de alguma grave lesão. Enquanto a percepção sensorial se fizer anormalmente no homem, através da porta comum dos cinco sentidos, um artista diante de um gato não poderá "sentir" senão um gato, e é falsa a "interpretação" que o bichano fizer um "totó", um escaravelho ou um amontoado de cubos transparentes. (LOBATO, 1917, n.p.)

O autor se destaca e separa seu auditório, como se observa na passagem abaixo, em que ele se considera o reflexo da opinião do auditório. E se avalia como "os que vêem normalmente as coisas", e dessa forma, insere-se no grupo de pessoas "normais", subjugando o restante e os colocando como outra espécie "formada pelos que vêem anormalmente a natureza". Como no trecho abaixo:

Julgamo-la, porém,
merecedora da alta
homenagem que é tomar a
sério o seu talento dando a
respeito da sua arte uma
opinião sinceríssima, e
valiosa pelo fato de ser o
reflexo da opinião do
público sensato, dos
críticos, dos amadores, dos
artistas seus colegas e...
dos seus apologistas. Dos
seus apologistas sim,
porque também elles
pensam deste modo... por
trás. (LOBATO, 1917, n.p.).

Lobato progride articulando sobre o que considera as características da Arte Moderna, tendo em vista que a considera anormal e teratológica, ou seja, monstruosa, absurda. Loucura advinda de mentes perturbadas e psicoses, onde não há sinceridade, só arte dissimulada e fingida.

Portanto, menciona a escola acadêmica quando faz alusão as medidas de proporção e equilíbrio na forma e na cor, consideradas as corretas por ele, que prossegue discorrendo sobre como se configura 0 modo correto do sentir.

Conclui, portanto, que o sentir de maneira cubista e futurista significa dizer que o mundo ao nosso redor precisa ter as mesmas proporções, o que é forçoso quanto ao sentir, se esse sentimento for desadequado quanto ao que se vê no mundo natural

\section{FIGURAS RETÓRICAS}

Todo o discurso utiliza-se da figura retórica do sarcasmo, por exemplo, quando se refere à "percepção sensorial" anormal no homem, por meio dos cinco sentidos, ou ainda quando vocifera sobre a "falsa interpretação" e compara a arte ao "totó" de um gato.

Lobato faz alusão às novas teorias plásticas e às escolas plásticas europeias quando diz que os artistas "interpretam a natureza à luz de teorias efêmeras", ou seja, passageiras, e quando discorre "sob a sugestão estrábica de escolas rebeldes". O termo estrábico se refere de forma conotada a um desvio ocular que faz com que os olhos não consigam fixar um mesmo ponto ao mesmo tempo. Já sob a forma figurada, a que nos interessa, refere-se a uma incapacidade de discernimento, de "ver de forma correta", sugerindo que a visão das escolas mencionadas está distorcida e incorreta. Para tanto, a alusão é uma figura retórica do pensamento, sendo o "emprego de palavras ou expressões que exprimem um pensamento indireto". (TAVARES, 1978, p. 345).

O autor prossegue comparandoas à furúnculos, e Malfatti a uma estrela cadente que brilha por um instante e desaparece para 
sempre, ou seja, reforça que seu sucesso é passageiro. A força passional é constatada aqui, a paixão que move o ethos de Lobato ao escrever esse artigo advém da exposição, e essa paixão é transmitida ao seu auditório.

Percebe-se que por todo o texto o escritor faz uso retórico das figuras de linguagem e do pensamento, tais como a símile ou comparação, quando emparelha as escolas à furúnculos, pois a símile, conforme Tavares (1978, p. 350), é o confronto ou comparação de dois ou mais elementos em que se depreende algum ponto de contato.

Assim, Lobato utiliza-se das figuras do pensamento alusão, apóstrofe, prosopopeia, hipérbole e outras. Para Tavares (1978, p. 343), as figuras retóricas de pensamento "apresentam sua consistência no pensamento, emoção ou paixão que as palavras ou expressões devam traduzir".

Por meio do texto, concebe-se também que Lobato faz uso de tropos, como a metáfora, para estabelecer as características de cada "tipo" de artista. Para Quintiliano (apud Perelman; Olbrechts-Tyteca, 1996, p. 453) "a metáfora é um tropo, ou seja, uma 'mudança bem-sucedida de significação de uma palavra ou de uma locução'”.

Lobato emprega também outras figuras retóricas, tais como anáfora, anadiplose, diácope, pleonasmo. Que são empregadas por repetição ou excesso. Sempre como forma de convencer o auditório, tornando o discurso mais rico e comovente. (TAVARES, 1978, p. 329)
Acordamos com o linguista Reboul quando esse demonstra como as figuras são um ponto essencial de um discurso, e completa que elas são "oratórias por contribuírem para agradar ou comover, mas são também argumentativas no sentido de exprimirem um argumento condensando-o, tornando-o mais contundente". (REBOUL, 2004, p. XVIII).

A figura retórica mais utilizada foi a anáfora, sendo a repetição da mesma palavra ou expressão no início de frases, período ou versos. (TAVARES, 1978, p. 329).

Lobato discorre, "São produtos de cansaço e do sadismo de todos os períodos de decadência: são frutos de fins de estação, bichados ao nascedouro", ou ainda neste outro fragmento, "Caricatura da cor, caricatura da forma caricatura que não visa, como a primitiva, ressaltar uma idéia cômica, mas sim desnortear, aparvalhar o espectador". (LOBATO, 1917). Concebe-se que o escritor se servia da repetição para realçar as ideias apresentadas, dando vigor a sua fala.

Prossegue repetindo termos para intensificar seu discurso, dando a ele aspectos de vasto conhecimento na área da pintura. Como se observa no trecho a seguir

Como se não fosse moderna, moderníssima, toda a legião atual de incomparáveis artistas do pincel, da pena, da águaforte, da dry point que fazem da nossa época uma das mais fecundas em obras-prima de quantas deixaram marcos de luz na história da humanidade. (LOBATO, 1917, n.p.).
Nesta outra passagem, Lobato vocifera, "dos seus apologistas.Dos seus apologistas sim, porque também eles pensam deste modo... por trás". Concebe-se aqui que as repetições elaboradas pelo escritor favorecem seu discurso, dando ênfase e realçando ideias, além de demonstrar seu conhecimento na área plástica.

A metonímia também é utilizada pelo escritor, e conforme Fiorin:

$$
\begin{aligned}
& \text { A metonímia é uma } \\
& \text { difusão semântica. No } \\
& \text { eixo da extensão, um } \\
& \text { valor semântico } \\
& \text { transfere-se a outro, num } \\
& \text { espalhamento sêmico. } \\
& \text { Com isso, no eixo da } \\
& \text { intensidade, ela dá uma } \\
& \text { velocidade maior ao } \\
& \text { sentido, acelerando-o, } \\
& \text { pois, ao enunciar, por } \\
& \text { exemplo, um efeito, já se } \\
& \text { enuncia também a causa, } \\
& \text { suprimindoraso etapas } \\
& \text { enunciativas. (FIORIN, } \\
& \text { 2014, p. 37). }
\end{aligned}
$$

Nesse trecho, Lobato emprega a metonímia quando troca o termo "as obras plásticas" pelo termo "Picasso", dizendo, "estas considerações são provocadas pela exposição da Sra. Malfatti, onde se notam acentuadíssimas tendências para uma atitude estética forçada no sentido das extravagâncias de Picasso e companhia". (LOBATO, 1917, n.p.).

Perscrutando 0 artigo identifica-se a figura da prosopopeia ou personificação (prosopopoía do grego, significando "personificação") que conforme Fiorin (2014, p 51) é "um alargamento do alcance semântico de termos designativos de entes abstratos ou concretos não humanos pela atribuição a eles de traços próprios do ser humano". 
Um trecho em que o escritor se utiliza da prosopopeia para intensificar 0 sentido, despertando paixões no auditório, fala sobre os eventuais elogios que Malfatti possa estar recebendo, "Entretanto, se refletir um bocado, verá que a lisonja mata e a sinceridade salva". Assim, ele personifica a lisonja quando dá a ela a capacidade de matar e à sinceridade a competência de salvar, dando a eles vivacidade, ares de vida, e reforçando seu argumento.

Lobato discorre sobre a Arte Moderna:

De há muitos já que a estudam os psiquiatras em seus tratados documentando-se nos inúmeros desenhos que ornam as paredes internas dos manicômios. A única diferença reside em que nos manicômios esta arte é sincera, produto ilógico de cérebros transtornados pelas mais estranhas psicoses; e fora deles, nas exposições públicas, zabumbadas pela imprensa e absorvidas por americanos malucos, não há sinceridade nenhuma nem nenhuma lógica, sendo mistificação pura. (LOBATO, 1917, n.p.)

Nesse trecho, evidencia-se o exagero em que $\mathrm{O}$ escritor descreve a Arte Moderna, enfatizando os aspectos que ele toma como "anormais", exagerando quando diz que de há muito a estudam, a única diferença, é produto ilógico, não há sinceridade, nem lógica, utilizando, para tanto, a figura hipérbole, que conforme Fiorin (2014, p. 75) significa "'ação de lançar por cima ou além”; depois, 'ação de ultrapassar ou passar por cima'; daí, 'excesso', 'amplificação crescente') é o tropo em que há um aumento da intensidade semântica".
Compreende-se, nos trechos citados, que a utilização das figuras auxilia o escritor a demonstrar seu ponto de vista de forma intensificada e, com isso, chamar a atenção do auditório. Essa parte do discurso é a narração, que conforme Meyer (2007b, p. 47) "expõe o desenrolar dos fatos como eles aconteceram ou podem acontecer".

Na narração, Lobato explicita a seu público, de forma riquíssima, sua visão sobre a arte, sobre Malfatti e sobre os que a apoiaram, por meio das considerações que ele profere sobre a exposição da artista, e menciona também que a exposição possui tendências forçadas, fazendo alusão ironicamente a Picasso e companhia, ou seja, zombando dos artistas modernistas e suas obras.

É durante a narração que o escritor se utiliza de diversos argumentos retóricos para persuadir seu auditório, levando-o a sentir determinadas paixões.

Como exemplo, tem-se o seguinte fragmento, no qual se utiliza $O$ argumento do exemplo para demonstrar a seu auditório que as pinturas de Malfatti não podem ser consideradas arte, pois são diametralmente opostas das grandes pinturas de Leonardo a Steves, de Velásques a Sorolla, de Rembrandt a Whistler:

Que nos perdoe a talentosa artista, mas deixamos cá um dilema: ou é um gênio O Sr. Bolynson e ficam riscados desta classificação, como insignes cavalgaduras, a coorte inteira dos mestres imortais, de
Leonardo a Steves, de Velásques a Sorolla, de Rembrandt a Whistler, ou... vice-versa. Porque é de todo impossível dar o nome da obra de arte a duas coisas diametralmente opostas. (LOBATO, 1917, n.p.)

iPara o linguista Fiorin (2018, p. 185) no argumento pelo exemplo "formulamos um princípio geral a partir de casos particulares ou da probabilidade de repetição de casos idênticos". Ou seja, no artigo Lobato se utilizou de obrasprimas já conceituadas e afirmadas como arte para demonstrar que como as pinturas de Malfatti não se parecem com elas, então não podem ser consideradas obras de arte.

Por fim, a peroração, que de acordo com Meyer (2007a, p. 25), "conclui, mostrando a adequação da solução ao problema submetido a exame", caracteriza-se, no artigo analisado, com passagem em que Lobato finaliza seu discurso, manifestando que haverá elogios à Malfatti, contudo tais lisonjas não são sinceras, e que os verdadeiros amigos da artista (ele se inclui) devem dizer-Ihe a verdade quando à sua obra.

Há de ter essa artista ouvido numerosos elogios à sua nova atitude estética. Há de irritar-lhe os ouvidos, como descortês impertinência, esta voz sincera que vem quebrar a harmonia de um coro de lisonjas. Entretanto, se refletir um bocado, vera que a lisonja mata e a sinceridade salva. O verdadeiro amigo de um artista não é aquele que o entontece de louvores, e sim o que the dá uma opinião sincera, embora dura, e the traduz chãmente, sem reservas, o que todos pensam dele 
por detrás. Os homens têm o vezo de não tomar a sério as mulheres. Essa é a razão de thes derem sempre amabilidades quando elas pedem opinião. Tal cavalheirismo é falso, e sobre falso, nocivo. Quantos talentos de primeira água se não transviaram arrastados por maus caminhos pelo elogio incondicional e mentiroso? E tivéssemos na Sra. Malfatti apenas uma "moça que pinta", como há centenas por aí, sem denunciar centelhas de talento, calar-nos-íamos, ou talvez lhe déssemos meia dúzia desses adjetivos "bombons" que a crítica açucarada tem sempre à mão em se tratando de moças. Julgamo-la, porém, merecedora da alta homenagem que é tomar a sério o seu talento dando a respeito da sua arte uma opinião sinceríssima, e valiosa pelo fato de ser o reflexo da opinião do público sensato, dos críticos, dos amadores, dos artistas seus colegas e... dos seus apologistas. Dos seus apologistas sim porque também eles pensam deste modo... por trás. (LOBATO, 1917, n.p.)

Observa-se o uso das metáforas quando ele diz que talvez fosse dado adjetivos "bombons", ou seja, adjetivos doces a seus ouvidos. Percebe-se que tal termo é colocado entre aspas, justamente para evidencia-lo e apresentá-lo ironicamente. Nota-se também que Lobato se coloca como porta-voz de seu auditório e também de seus aliados, já que toma os modernistas como desonestos e fingidos, hipócritas e mentirosos.

\section{PAIXÕES E VALORES}

Perelman e Olbrechts-Tyteca
(1966, p. 84) discorrem também sobre os valores em uma argumentação, quando proferem que "a existência dos valores, como objetos de acordo que possibilitam uma comunhão sobre modos particulares de agir, é vinculada à ideia de multiplicidade dos grupos".

Salienta-se que os valores do auditório que leu o artigo e comungou com ele são valores comuns ao orador e ao auditório, além, do despertar das paixões, resultando na adesão observada.

Ainda para os autores: Para os antigos, os enunciados concernentes ao que chamamos de valores, na medida em que não eram tratados como verdades indiscutíveis, estavam englobadas, com toda a espécie de afirmações verossímeis, no grupo indiferenciado das opiniões. (PERELMAN; OLBRECHTS-TYTECA, 1996, p. 84)

Pode-se conceber como as opiniões ou pathe despertados garantem a adesão do auditório, sobretudo quando a enunciação está pautada em valores plásticos ou artísticos comuns com o ouvinte, tais como o Academicismo, no qual a arte ou a pintura deveriam retratar o real, em busca da perfeição estética e do considerado belo.

Assim, quando Malfatti produz obras influenciadas pelas correntes artísticas vindas da Europa[7], ela demonstra valores abstratos que não existiam até então na doxa da época, dissociando-se dos valores acadêmicos e, assim, despertando paixões tanto de ira, irritação e inveja, quando de amizade, amabilidade, devoção e amor. Sobre isso, Perelman e Olbrechts-Tyteca (1996, p. 84) discorrem que "os valores intervêm, num dado momento, em todas as argumentações".

Portanto, por meio da exibição dos valores vigentes na época, o discurso despertou paixões, tanto dos que concordaram, como dos que discordaram, pois, "um mesmo enunciado, conforme o lugar que ocupa no discurso, conforme o que enuncia, o que refuta, o que corrige, poderá ser compreendido como relativo ao que se considera comumente fato ou ao que se considera valor". (PERELMAN; OLBRECHTS-TYTECA, 1996, p. 85).

Os autores ainda complementam que "recorre-se a eles para motivar o ouvinte a fazer certas escolhas em vez de outras e, sobretudo, para justificar estas, de modo que se tornem aceitáveis e aprovados por outrem". (PERELMAN: OLBRECHTS-TYTECA, 1996, p. 84-85)

Assim, compreende-se a dicotomia estabelecida fortuitamente entre Malfatti e Lobato, visto que, os valores pregados por cada um são distintos. Malfatti ofereceu critérios ou valores abstratos para modificar a ordem estabelecida quando propôs uma nova arte com sua exposição, apresentando ao auditório da época uma nova proposta plástica e novos valores estéticos para a sociedade. Já Monteiro Lobato, em sua crítica, receoso com as mudanças trazidas pela artista, não desejava a mudança e, devido a isso, almejava manter 
seus valores acadêmicos e, portanto, vangloriava o valor concreto do academicismo.

Quando os autores discorrem "não há razão para expor incompatibilidades", constata-se que Lobato contribui com a adesão do auditório com a Arte Moderna, já que compara os dois tipos de escolas plásticas, pois Malfatti trouxe as incompatibilidades junto com suas deformações e cores acentuadas, e o escritor com sua comparação das incompatibilidades

Academismo e do Modernismo. Porquanto, a comparação estabelecida contribuiu para que 0 auditório sentisse interesse pela exposição, ou ao menos, curiosidade em conhecer a pintura de Malfatti.

Para corroborar com o interesse destacado pelas pinturas, Meyer afirma que "a paixão começa pela expressão subjetiva de uma questão vista sob o ângulo do prazer e do desprazer". Dessa forma, manifesta-se que a paixão está intrínseca ao homem e que um mesmo discurso pode despertar tanto a ira como a amabilidade, já que se configura como algo baseado em uma emoção despertada individualmente e que cabe a interpretação (MEYER, 2007, p. 36-37).

Assim, o estagirita concebe que as emoções ou paixões despertadas em um auditório "são as causas que fazem alterar os seres humanos e introduzem mudanças nos seus juízos, na medida em que elas comportam dor e prazer, tais como a ira, a compaixão, o medo e outras semelhantes, assim como suas contrárias".

(ARISTÓTELES, 2015, p. 116)
E conforme Bechara, quando se utiliza sufixos em substantivos indica-se mudanças em sua significação, seja para engrandecer algo ou torná-lo ínfimo, ou seja, utilizase de acordo com a forma que quer referir-se a algo ou alguém, por isso, o gramático demonstra que (2009, p. 140) "os substantivos apresentamse com a sua significação aumentada ou diminuída, auxiliados por sufixos derivacionais". E acrescenta:

Fora da ideia de tamanho, as formas aumentativas e diminutivas podem traduzir o nosso desprezo, a nossa crítica o nosso pouco caso para certos objetos e pessoas, sempre em função da significação lexical da base, auxiliados por uma entonação especia (eufórica, critica, admirativa, lamentativa, etc.) e os contornos que envolvem falante $e$ ouvinte. (BECHARA, 2009, p. 141).

Com o exposto, percebe-se o uso do termo "quadrinhos" de forma pejorativa por Lobato no momento em que supostamente qualificava a artista -, para se referir aos quadros de Malfatti, demonstrando seu desprezo pela obra da artista, sua ira e inveja.

Segundo Aristóteles (2015, p. 117, 1378b), "toda ira é acompanhada de certo desprezo. Resultado da esperança que se tem de uma futura vingança". E completa, "de fato, existe prazer em pensar que se pode alcançar o que se deseja; mas, como ninguém deseja o que the é manifestamente impossivel, o irascivel deseja o que the é possível".
Assim, o pathos de cólera é definido por Aristóteles (2000, p. 7) como um desejo "acompanhado de tristeza, de vingar-se ostensivamente de um manifesto desprezo por algo que diz respeito a determinada pessoa ou a algum dos seus quando esse desprezo não é merecido".

A paixão da ira, por sua vez, evidencia como sucumbir à hybris, do grego, "toda espécie desmedida, de exagero ou de excesso no comportamento da pessoa orgulho, insolência, arrebatamento etc.", e dessa forma, pode agigantar os sentimentos ali presentes. Bastante empregado na filosofia moral, esse termo se opõe a medida, equilíbrio (DICIONÁRIO, 2018, online). Portanto, O exagero relatado pode acometer qualquer paixão, pois o despertar das emoções no auditório não pode ser medido.

\section{CONSIDERAÇÕES FINAIS}

Pelo exposto, concebe-se que o artigo A propósito da exposição Malfatti é uma reação passional à exposição mencionada, dando ênfase em paixões e emoções, por meio de recursos retóricos e argumentativos, como figuras e tropos que, de certa forma, contribuíram com a disseminação da Arte Moderna representada pela exposição.

O discurso de Lobato é estruturado de forma a evidenciar os valores artísticos em que o autor acreditava e, dessa forma, incita seu auditório a segui-lo em tais ideais e valores. Assim, o autor é bemsucedido em corroborar com sua visão sobre as artes plásticas, pois a figura de autoridade the atribui poder sobre tais questões. Portanto, o 
discurso de Lobato apresentase e estrutura-se como explicitamente argumentativo, atingindo seu intento quando o auditório crê em seu posicionamento. Por outro lado, essa mesma argumentação contrária à Arte Moderna ali apresentada contribui para a disseminação da mesma, conferindo-Ihe propagação e visibilidade.

Para tanto, o exórdio traz para o auditório o contexto do assunto a ser discutido, oferecendo uma comparação entre o Academicismo e o Modernismo, com seus respectivos artistas plásticos, prestigiando uns e desfavorecendo outros; instigando 0 auditório estratégica e retoricamente a fazer parte de um grupo ou do outro e, com o argumento de autoridade, evidencia seu posicionamento e induz seu auditório, por meio do seu próprio exemplo.

Portanto, Lobato levanta argumentos para apoiá-lo em seu discurso e, por meio de metáforas desconstrói o ethos da artista plástica Malfatti e do movimento moderno que ela proporcionou e iniciou com sua exposição. Movimento artístico que reverbera até hoje.

Por fim, na peroração, finaliza seu discurso com o intuito claramente não atingido de elogiar Malfatti, mas que pelos termos utilizados ainda prosseguia em sua catilinária, estendendo-a também aos que apoiaram a pintora.

Concebe-se, portanto, o ethos de escritor conceituado e crítico que Lobato demonstrou, alcançando seu auditório com um discurso homogêneo, destinado a evidenciar o "absurdo" que era para ele aquela dita nova arte e, assim, ganha adeptos à sua causa, pelo despertar de paixões, por meio de valores já intrínsecos no auditório. Além, é claro, de idealizar 0 artigo como resposta passional à exposição, demonstrando ira, irritação, inveja e até ódio pelas obras de Malfatti.

Conclui-se, por conseguinte, como as provas retóricas no discurso foram fundamentais para que Lobato despertasse o auditório por meio das paixões. Evidencia-se assim, seu desprezo e inveja pela nova arte como ruptura plástica e artística, além de social e política, até porque ele prezava o Academicismo iminentemente ameaçado diante do advento do Modernismo. Seu uso apropriado das figuras retóricas, bem como sua figura de autoridade no assunto discutido e no contexto cultural da época contribuíram favoravelmente para que ele convencesse e persuadisse seus pares, contudo, é manifesto que essas mesmas provas retóricas atribuíram ao seu discurso o "pavor" e a "ameaça" que Malfatti e suas obras provocaram.

\section{NOTAS}

[1] O presente trabalho foi realizado com apoio da Coordenação de Aperfeiçoamento de Pessoal de Nível Superior - Brasil (CAPES) - Código de Financiamento 88882.365810/2019-01

[2] A primeira exposição de Anita Malfatti ocorreu em 1914 e foi intitulada "Exposição de estudos de pintura Anita Malfatti" elaborada como prova de aptidão para pleitear - Pensionato Artístico do Estado de São Paulo, bolsa do Governo para a área artística. Foram selecionadas 33 obras (BATISTA, 2006, p. 84-85).
[3] Posteriormente publicado com o título de Paranóia e Mistificação? no livro Idéias de Jeca Tatu, em 1919

[4] Expressão de Mário da Silva Brito (BATISTA, 2006, p. 17)

[5] LOBATO, Monteiro. Paranóia e mistificação? MAC USP. Disponível em: https://bit.ly/3euOysL. Acesso em: 20 maio 2018.

[6] O filósofo Aristóteles nasceu em Estagira, cidade da Macedônia.

[7] Fauvismo que emprega a explosão de cores de maneira exagerada e expressiva; Cubismo, com o uso de formas geométricas; e, também o Expressionismo, tendência que utilizava a expressão de sentimentos em formas distorcidas, exageradas, repletas de cores para impactar 0 auditório,

\section{REFERÊNCIAS}

ARISTÓTELES. Retórica das Paixões. São Paulo: Martins Fontes, 2000.

Retórica. São Paulo: WMF Martins Fontes, 2015

BATISTA, Marta Rossetti. Anita Malfatti no tempo e no espaço: Biografia e estudo de obra. São Paulo: Ed. 34; Edusp, 2006

BECHARA, Evanildo. Moderna gramática portuguesa. Rio de Janeiro: Nova Fronteira, 2009.

COELHO, Frederico. A semana sem fim. Celebrações e memória da Semana de Arte Moderna de 1922. Rio de Janeiro: Casa da Palavra, 2012.

DICIONÁRIO de Filosofia. Hybris ou Hubris. Disponivel em: https://bit.ly/2TOyOHo. Acesso em: 20 maio 2018.

FIORIN, José Luiz. Figuras de retórica. São Paulo: contexto, 2014.

Argumentação. São Paulo: Contexto, 2018

LOBATO, Monteiro. Paranóia e mistificação? MAC USP. Disponível em: https://bit.ly/3euOysL. Acesso em: 20 maio 2018. 
MEYER, Michel. Questões de retórica: linguagem, razão e sedução. Portugal: Edições 70, 2007a.

$2007 b$

A retórica. São Paulo: Ática,

PERELMAN, Chaïm; OLBRECHTS-

TYTECA Lucie. Tratado da

argumentação: a nova retórica. São

Paulo: Martins Fontes, 2005.

REBOUL, Olivier. Introdução à retórica.

São Paulo: Martins Fontes, 2004

TAVARES, Hênio. Teoria literária. Belo

Horizonte: Itatiaia, 1978

Artigo recebido em: 21 Jan 2020. I Artigo aprovado em: 03 Maio 2020.

[i] Doutoranda em Linguística pelo Programa de Pós-Graduação na Unifran - Universidade de Franca (com ênfase em Semiótica). Mestra em Linguística pelo mesmo programa (com ênfase em Retórica). Graduada em Letras - Tradutor e Intérprete pela mesma instituição.

Orcid: https://orcid.org/0000-0003-0258-5092

E-mail: chrystina_13@hotmail.com

[ii] Doutor em Ciências da Comunicação, na área de Estudos dos Meios e da Produção Mediática, pela Escola de Comunicação e Artes (ECA) da Universidade de São Paulo (USP), Mestre em Comunicação Midiática pela Universidade Estadual Paulista Júlio de Mesquita Filho (UNESP). Graduado em Desenho Industrial (habilitação em Programação Visual, 1995).

Orcid: https://orcid.org/0000-0002-5677-0608.

E-mail: fferreiradg@uol.com 